\title{
A Study Of Fear Provoking Environmental Cues Among Female STUdeNTS ON UNIVERSITY CAMPUS' THRESHOLd AREA
}

\section{Kajian Isyarat Lingkungan Pemicu Rasa Takut Mahasiswi Pada Area Ambang Kampus Universitas}

\author{
Enira Arvanda ${ }^{1 *}$, Nevine Rafa Kusuma ${ }^{2}$, Niken Rahadiani M. ${ }^{3}$ \\ Department of Architecture Universitas Indonesia ${ }^{1}$ \\ Email: enira.arvanda28@ gmail.com * \\ Department of Architecture Universitas Indonesia ${ }^{2}$ \\ Department of Architecture Universitas Indonesia ${ }^{3}$
}

\begin{abstract}
University campus is widely perceived as a safe and controlled environment for students. However, its perimeter area that serves as a threshold between the campus and its surrounding neighborhood, is mostly less developed. Hence, it might become a potential site for unlikely events such as a crime. This paper will investigate women students' perceived risk on the campus threshold area and identify environmental cues that provoke fear of potential risk. Moreover, it also questions how the students relate their sense of safety to a setting. To confirm the hypothesis, we distributed a structured questionnaire using an online survey platform. As a result, several environmental cues have been identified as fear-provoking and the findings confirm female students' tendency to assess potential risk from available environmental cues.
\end{abstract}

Keywords: perceived risk, fear, environmental cues, female students, campus threshold

\section{PENDAHULUAN}

Universitas Indonesia (UI) adalah salah satu universitas negeri terbesar dan tertua di Indonesia, yang memiliki fasilitas kampus mumpuni dengan luas area mencapai 320 hektar. Lansekap kampus UI memiliki atmosfer yang sangat 'hijau', hanya $25 \%$ berupa bangunan yang memfasilitasi pendidikan, riset dan kemahasiswaan, sementara $75 \%$ sisanya adalah lahan hijau yang berwujud hutan kota ("Tentang Universitas Indonesia," n.d.). Kampus yang sebagian besar terletak di kota Depok ini (sebagian areanya masih berada di wilayah DKI Jakarta) berbatasan dengan area permukiman dan area komersial (gambar 1). Perimeter kampus UI ditandai dengan pagar pembatas berwarna kuning, yang oleh mahasiswa dan warga setempat kerap disebut dengan 'pagar kuning'.
Di dalam fasilitas kampus, mahasiswa merasa dapat melakukan berbagai kegiatan tanpa harus mengkhawatirkan keselamatannya. Persepsi ini didukung dengan adanya manajemen kelola fasilitas dan sistem keamanan yang cukup ketat oleh pihak pengelola kampus. Namun demikian, berdasarkan wawancara yang kami lakukan dengan beberapa mahasiswa dari Program Studi Arsitektur Interior di Departemen Arsitektur UI, terdapat beberapa area pada lingkungan kampus UI yang dikeluhkan kurang aman, dan dipersepsikan sebagai area yang menakutkan. Karakteristik lansekap yang natural dengan vegetasi beragam dan lebat dianggap memiliki kontribusi terhadap perasaan takut. Berdasarkan wawancara tersebut, peneliti merasa tertarik untuk membahas fenomena ini lebih lanjut 
dengan berfokus kepada mahasiswi sebagai subyek penelitian.

Tulisan ini dipicu oleh penelitian serupa mengenai hubungan antara lingkungan kampus, rasa takut dan jender (Day, 1994; Fisher \& May, 2009; Mellgren \& Ivert, 2018). Namun, berbeda dengan penelitian-penelitian sebelumnya yang membahas lingkungan kampus secara umum, penulis akan memfokuskan lingkup penelitian pada area ambang (threshold) kampus. Area ambang pada kampus UI adalah area transisi yang bertindak sebagai batas pinggir (edge) yang mengelilingi keseluruhan kampus, dan berbatasan langsung dengan bagian dari kota Depok maupun dengan wilayah Jakarta Selatan (lihat gambar 1).

Area transisi merupakan ruang antara (inbetween space) satu ruang dengan lainnya yang memiliki karakteristik unik, yaitu dipengaruhi oleh kualitas ruang yang diperantarainya. Pada ruang transisi di lingkungan kampus, atmosfer interior kampus yang serba teratur dan terkontrol mulai berbaur dengan suasana lingkungan kota yang lebih dinamis. Pada sisi luarnya, pada umumnya terhubung dengan akses lingkungan dan akses menuju sarana transportasi umum. Lingkungan di sekitar ambang juga menjadi area penunjang kampus, sehingga berbagai fasilitas akomodasi dan penunjang kehidupan sehari-hari. Oleh karenanya, area ambang ini diakses oleh mahasiswa secara rutin dan sering, terutama bagi yang bertinggal di sekitar kampus.

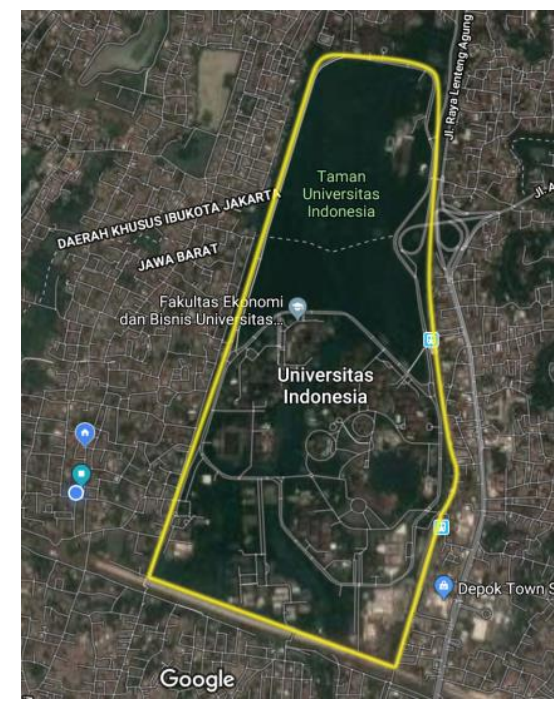

Gambar 1. Ambang pada kampus UI
Menurut laporan mengenai kriminalitas di kampus UI yang diterbitkan oleh UPT Pengamanan Lingkungan Kampus UI pada tahun 2013, pada kurun waktu 2010-2013 terdapat berbagai laporan tindak kriminalitas yang terjadi di dalam lingkup kampus dan area sekitarnya (PLK UI, 2013). Jenis tindakan dilaporkan mulai dari tindak kriminal ringansedang seperti pelanggaran seksual, pencurian, penjambretan, hingga tindak kriminal berat seperti pembunuhan. Berita mengenai kriminalitas yang terjadi di dalam kampus juga pernah beberapa kali tercantum di halaman koran nasional (Nurdiansyah, 2015; Putra, 2018). Pada tahun 2015 terdapat satu artikel di laman web unofficial komunitas mahasiswa dan alumni UI (www.anakui.com) yang membahas mengenai kriminalitas yang kian merajalela di dalam kampus UI (Dwika, 2015), yang menandakan keresahan mahasiswa akan tindak kejahatan dan keamanan mereka di dalam lingkungan kampus. Dengan adanya kejadian terkait krimalitas yang berulang, persepsi terhadap resiko keselamatan akan menjadi semakin tinggi. Berdasarkan fakta-fakta tersebut, persepsi rasa takut pada lingkungan kampus dan hubungannya dengan isyarat lingkungan (environmental cues) pada ambang (threshold) kampus menjadi relevan untuk dibahas.

Adapun tujuan dari penelitian ini bukan untuk membuktikan bahwa lingkungan kampus gagal memberikan rasa aman bagi mahasiswinya. Melalui tulisan ini, penulis ingin mengidentifikasi isyarat lingkungan yang dapat memicu persepsi rasa takut mahasiswi pada lingkungan kampus. Hasil penelitian ini diharapkan dapat berguna bagi pihak pengelola kampus maupun pemerintah kota setempat untuk lebih memperhatikan berbagai elemen ruang di lingkungan kampus dan wilayah kota yang berbatasan dengan kampus, yang dapat berpotensi menimbulkan rasa takut dan tidak aman.

\section{MATERI DAN METODE PENELITIAN}

\subsection{Kajian Literatur}

\subsubsection{Perempuan dan Rasa Takut akan Viktimisasi}

Usia dan jender merupakan faktor penting pada tingkatan rasa takut terhadap tindak kejahatan (Fisher \& May, 2009; Mellgren \& Ivert, 2018). 
Berdasarkan beberapa penelitian mengenai jender dan rasa takut akan tindak kejahatan (fear of crime), perempuan memiliki tingkatan rasa takut yang lebih tinggi dari laki-laki, hal ini dilatarbelakangi oleh persepsi terhadap kerentanan fisik perempuan, terutama pada masyarakat yang patriarkis (Loukaitou-sideris, 2012; Loukaitou-Sideris, Bornstein, Fink, Samuels, \& Gerami, 2009; Loukaitou-sideris \& Fink, 2008; Stanko, 1995). Rasa takut perempuan akan serangan seksual (sexual assault) lebih mendominasi apabila dibandingkan dengan rasa takut pada tindak kriminalitas yang bersifat non-seksual (Ferraro, 1996; Fisher \& Sloan, 2003), sehingga rasa takut terhadap serang seksual ini dapat 'membayangi' dan meningkatkan ketakutan perempuan terhadap tindak kriminalitas lainnya, yang diistilahkan oleh Ferarro (1996) sebagai "shadow of sexual assault".

Mellgren dan Ivert menyatakan bahwa viktimisasi seksual terhadap wanita muda lebih besar kemungkinannya daripada terhadap wanita dewasa (Mellgren \& Ivert, 2018). Namun demikian, Stanko (1995) menegaskan bahwa rasa takut terhadap kejahatan (fear of crime) dapat mendahului dan terkadang tidak berhubungan dengan tindak kejahatan yang sesungguhnya (actual crime), rasa takut ini disebabkan oleh emosi yang dipicu oleh naluri bahaya (sense of danger) akan keselamatan yang terancam, terutama terhadap tindak kejahatan yang dapat menyakiti fisik seseorang.

\subsubsection{Isyarat Lingkungan yang Memicu Rasa Takut}

Pengalaman spasial seseorang sangat bergantung kepada kemampuan kognitifnya, terutama dalam mencerna informasi temporal dan spasial dari lingkungan di sekitarnya (Fisher \& May, 2009). Dalam proses pemetaan kognitif (cognitive mapping), seseorang membuat penilaian berdasarkan kumpulan isyarat (clues) dari lingkungan-binaan yang telah dievaluasi keadaan maupun ketiadaan elemennya dengan seksama. Informasi yang dipersepsikan melalui proses ini akan berlaku sebagai peta kognitif yang menuntun keputusan dan perilaku seseorang. Rasa takut yang ditimbulkan oleh kondisi lingkungan dipersepsikan melalui mekanisme serupa; kondisi lingkungan dinilai berdasarkan persepsi akan resiko dan potensi bahaya yang mungkin terjadi (Rader, 2017). Dengan kata lain, respon individu terhadap ancaman viktimisasi tidak hanya berdasarkan emosi belaka (fear of crime), namun juga berdasarkan proses kognisi terhadap resiko (perceived risk) dan pembatasan perilaku (constrained behavior) (Rader, 2017). Berdasarkan teori Prospect and Refuge yang dikemukakan oleh Appleton, modifikasi perilaku yang terjadi saat seseorang berada dalam situasi yang beresiko merupakan upaya untuk penyelamatan diri (Appleton, 1984).

Namun demikian, terdapat perbedaan mendasar pada cara perempuan dan laki-laki dalam menilai isyarat lingkungan. Laki-laki tidak menilai situasi berdasarkan keadaan atau ketiadaan elemen lingkungan tertentu, melainkan cenderung menggunakan naluri dan kalkulasi strategi untuk keluar dari situasi yang membahayakan (Fisher \& May, 2009). Hal ini disebabkan laki-laki lebih percaya pada kekuatan fisiknya dan akan kemampuan melindungi dirinya sendiri. Sebaliknya, perempuan tidak mengandalkan kekuatan fisik, mereka lebih memilih tindakan pencegahan dengan memodifikasi perilaku pada lingkungan tertentu yang dipersepsikan tidak aman. Perbedaan cara menilai isyarat lingkungan antara siswa perempuan dan laki-laki ini menyebabkan isyarat lingkungan yang dianggap menimbulkan bahaya menjadi sedikit berbeda bobot penilaiannya (Fisher \& May, 2009). Menurut penelitian Fisher \& May, siswa Laki-laki menganggap sekelompok remaja yang berkumpul (loitering youth), yang merupakan isyarat sosial, sebagai potensi bahaya yang paling tinggi. Sementara, bagi perempuan isyarat yang dianggap memiliki resiko paling tinggi adalah tingkat pencahayaan yang kurang baik, yang merupakan isyarat lingkungan.

Kondisi fisik perempuan yang dipersepsikan lebih rentan menyebabkan mereka lebih beresiko menjadi korban tindakan kriminal. Perempuan juga cenderung membawa pengalaman viktimisasi di masa lampau dalam menghadapi situasi terkini (Loukaitou-Sideris, 2014). Loukaitou-Sideris memberi contoh bahwa sangat mungkin bagi perempuan untuk mengubah pola perjalanannya untuk mengatasi rasa takut mereka terhadap setting tertentu (Loukaitou-Sideris, 2014). 
Valentine beranggapan bahwa sebagian besar persepsi perempuan terhadap resiko bahaya dipengaruhi oleh karakteristik fisik tertentu dari lingkungan. Sehingga, desain ruang publik dapat mempengaruhi persepsi rasa aman perempuan dan keinginan mereka untuk menggunakan ruang tersebut (Valentine, 1990). Anggapan Valentine mengenai setting yang memicu rasa takut, memiliki prinsip yang sama dengan teori Fear and Refuge yang dikemukakan oleh Appleton. Menurut Appleton, kemampuan seseorang untuk dapat mengamati dan menerima informasi dari lingkungan sekitarnya (prospect) dan kemungkinan untuk berlindung atau bersembunyi (concealment) dapat mempengaruhi perilaku seseorang, bahkan menimbulkan modifikasi perilaku (Appleton, 1984).

Untuk kepentingan penulisan, agar penulis dapat menganalisis jenis isyarat lingkungan yang dapat memicu rasa takut, maka penulis merangkum beberapa indikator yang dikemukakan oleh Fisher \& May (2009), Loukaitou-Sideris (2014), Valentine (1990) dan Appleton (1984).

Tabel 1. Isyarat lingkungan dan isyarat sosial yang dapat memicu rasa takut

\begin{tabular}{|c|c|c|}
\hline \multicolumn{2}{|c|}{ Isyarat } & $\begin{array}{c}\text { Situasi yang } \\
\text { memicu rasa takut }\end{array}$ \\
\hline \multirow[t]{5}{*}{$\begin{array}{l}\text { Isyarat } \\
\text { Lingkungan }\end{array}$} & Pencahayaan & $\begin{array}{l}\text { Kegelapan, } \\
\text { pencahayaan yang } \\
\text { kurang baik }\end{array}$ \\
\hline & $\begin{array}{l}\text { Kemampuan } \\
\text { untuk } \\
\text { mengawasi } \\
\text { sekeliling dan } \\
\text { Kemungkinan } \\
\text { berlindung }\end{array}$ & $\begin{array}{l}\text { Sudut, pojok dimana } \\
\text { seseorang mungkin } \\
\text { bersembunyi; } \\
\text { perasaan } \\
\text { terkungkung, tidak } \\
\text { memungkinkan } \\
\text { untuk kabur }\end{array}$ \\
\hline & Vegetasi & $\begin{array}{lr}\text { Tanaman } & \text { yang } \\
\text { terlalu lebat, } \\
\text { memungkinkan } \\
\text { seseorang untuk } \\
\text { bersembunyi } \\
\text { baliknya. }\end{array}$ \\
\hline & $\begin{array}{l}\text { Visibilitas } \\
\text { (visibility) dan } \\
\text { Pengawasan } \\
\text { (surveillance) }\end{array}$ & $\begin{array}{l}\text { Ketidakmampuan } \\
\text { untuk melihat area } \\
\text { sekitar dengan jelas }\end{array}$ \\
\hline & $\begin{array}{l}\text { Kebersihan } \\
\text { dan Perawatan } \\
\text { (maintenance) }\end{array}$ & $\begin{array}{l}\text { Kotor, semrawut dan } \\
\text { tidak terpelihara, } \\
\text { adanya } \\
\text { vandalisme }\end{array}$ \\
\hline Isyarat Sosial & $\begin{array}{l}\text { Kehadiran } \\
\text { orang asing } \\
\text { (strangers) }\end{array}$ & $\begin{array}{l}\text { orang asing, } \\
\text { terutama anak muda } \\
\text { yang nongkrong atau } \\
\text { berperilaku } \\
\text { mencurigakan. }\end{array}$ \\
\hline
\end{tabular}

\begin{tabular}{|l|l|l|}
\hline & $\begin{array}{l}\text { Keberadaan } \\
\text { orang lain }\end{array}$ & $\begin{array}{l}\text { Situasi yang sangat } \\
\text { sepi, tidak adanya } \\
\text { orang lain di sekitar. }\end{array}$ \\
\cline { 2 - 3 } & $\begin{array}{l}\text { Keberadaan } \\
\text { aparat } \\
\text { keamanan }\end{array}$ & $\begin{array}{l}\text { Tidak adanya aparat } \\
\text { keamanan yang } \\
\text { dapat memberikan } \\
\text { perlindungan. }\end{array}$ \\
\hline
\end{tabular}

Sumber: (Appleton, 1984; Fisher \& May, 2009; Loukaitou-Sideris, 2014; Valentine, 1990)

Pada tabel 1 penulis juga menyertakan isyarat sosial sebagai indikator yang penting untuk analisis, karena isyarat sosial merupakan aspek yang tidak dapat dipisahkan dari setting lingkungan.

\subsection{Metode Penelitian}

\subsubsection{Subyek Penelitian}

Penelitian ini akan berfokus pada perempuan muda yang merupakan mahasiswa aktif pada Universitas Indonesia, pada jenjang strata satu (S1) maupun jenjang strata dua (S2/magister). Rentang Usia responden berkisar antara 17 tahun hingga 26 tahun, yaitu termasuk dalam kategori remaja akhir menurut Kementrian Kesehatan Republik Indonesia (2009).

Fokus penelitian pada mahasiswi didasari oleh beberapa alasan:

a) Wanita muda lebih rentan menjadi korban dan oleh karenanya lebih memiliki rasa takut dibandingkan dengan pria (Loukaitou-sideris, 2012; LoukaitouSideris, 2014; Stanko, 1995).

b) Wanita lebih memiliki kepekaan terhadap isyarat lingkungan yang menandakan potensi bahaya dan juga lebih peka terhadap gangguan sosial (LoukaitouSideris, 2014).

\subsubsection{Konteks Penelitian}

Fisher dan Sloan menyatakan bahwa wanita muda lebih rentan diviktimisasi dibandingkan dengan wanita usia matang (Fisher \& Sloan, 2003). Sehingga, sebuah kampus universitas merupakan konteks yang menarik untuk diteliti, dikarenakan memiliki populasi wanita muda dalam jumlah besar.

Dalam penelitian ini, area yang diobservasi difokuskan pada area ambang atau threshold dari kampus. Karakteristik dari ambang adalah terdapat kemungkinan untuk keluar atau masuk, sehingga menciptakan koneksi dan transisi dari satu ruang ke ruang lainnya (Boettger, 2014). 
Berdasarkan pendapat Boettger inilah, penulis melihat bahwa area yang mengelilingi ujung terluar (edge) wilayah kampus UI dan membatasinya dengan lingkungan kota di sekitarnya dapat disebut sebagai ambang kampus UI. Area ini diindikasikan oleh batas berupa pagar kuning di sepanjang kelilingnya. Pada penelitian ini, kami melakukan observasi pada 5 titik lokasi yang terdapat akses keluar dan masuk kampus. Kelima titik tersebut menghubungkan kampus dengan lingkungan sekitarnya. Titik lokasi yang diobservasi tersebut terdiri atas (lihat gambar 2):

A)Kukusan Kelurahan-Vokasi B) Kukusan Teknik C) Pondok Cina D) Gerbang Utama UI E) Barel (area di seberang Fakultas Hukum).

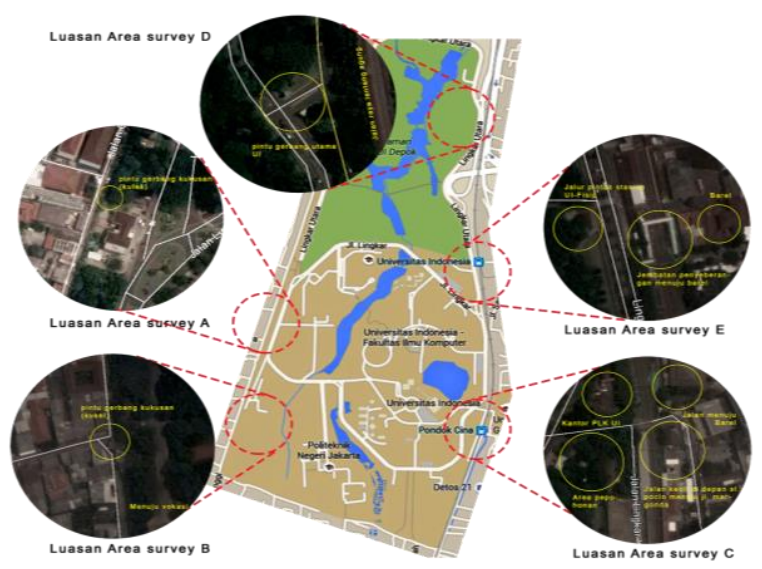

Gambar 2. Area yang diobservasi

Pada kelima lokasi yang diobservasi, karakteristik ambang (threshold) terlihat jelas, yaitu memiliki sifat ruang transisi dan kualitas yang dipengaruhi oleh kondisi ruang 'luar' maupun 'dalam' yang ia hubungkan. Ambang pada kampus UI masih memiliki aspek kontrol dan keteraturan yang kuat, namun memiliki atmosfer dinamis yang dipengaruhi oleh kondisi lingkungan kota di sekitarnya.

\subsubsection{Pengumpulan Data}

Pada bulan November 2018, tim peneliti menyelenggarakan survei melalui media online. Survei ini menargetkan responden perempuan yang masih terdaftar sebagai mahasiswi aktif di Universitas Indonesia. Adapun tujuan dari pelaksanaan survei adalah untuk mengumpulkan informasi mengenai isyarat lingkungan (environmental cues) yang dianggap berpotensi menimbulkan rasa takut (fear-provoking). Selain itu, survei ini juga menggali informasi mengenai tipe isyarat lingkungan yang dianggap dapat menghilangkan rasa takut (fear-relieving) akan suatu lingkungan.

Survei yang disebarkan melalui platform Google Form ini dibagi menjadi empat bagian yang terdiri atas kombinasi pertanyaan tipe tertutup, open-ended dan pertanyaan pilihan dengan skala Likert. Bagian pertama berisi pertanyaan mengenai informasi umum para responden. Bagian kedua memuat pertanyaan mengenai pengalaman masa lalu responden yang terkait dengan viktimisasi dan tindak kriminalitas. Bagian ketiga membahas mengenai isyarat lingkungan dan persepsi rasa takut responden. Bagian keempat berisi pertanyaan mengenai perlakuan lingkungan (environmental treatment) yang dianggap dapat meredakan atau menghilangkan (fearrelieving) rasa takut responden.

Terdapat beberapa kelemahan pada metode penyebaran kuesioner online, misalnya variasi sampel yang tidak cukup dapat mewakili keseluruhan populasi mahasiswi di Universitas Indonesia. Responden sebagian besar (91\%) berasal dari Fakultas Teknik, dan lebih dari separuhnya (61\%) berasal dari Departemen Arsitektur. Hal ini disebabkan oleh cara distribusi survei online melalui perwakilan mahasiswa, sehingga link survei hanya menyebar di kalangan mahasiswi tim peneliti, yaitu di lingkungan Fakultas Teknik. Meskipun link survei sudah ditampilkan di media sosial Badan Eksekutif Mahasiswa (BEM) dari berbagai fakultas, rupanya cara tersebut kurang efektif, dan tidak cukup menggugah mahasiswi untuk berpartisipasi. Kedepannya, tim peneliti akan lebih berhati-hati lagi dalam menentukan metode penyebaran kuesioner, sehingga bisa didapatkan responden yang lebih banyak dan lebih mewakili semua fakultas yang ada di lingkungan UI.

\subsubsection{Metode Pengukuran Data}

Melalui survei online yang dilakukan, tim mendapatkan jumlah sampel sebanyak 102 orang mahasiswi $(\mathrm{N}=102)$. Data ini kemudian dianalisis dengan menggunakan statistik deskriptif. Kami mengukur kecenderungan rasa takut terhadap isyarat lingkungan dengan pertanyaan yang menggunakan skala Likert. Hasil diukur dengan menggunakan median, untuk melihat tendensi terhadap suatu hal. 


\section{HASIL DAN DISKUSI}

\subsection{Analisis Karakteristik Responden}

Bagian pertama survei terdiri atas pertanyaan mengenai identitas responden (lihat tabel 2). Keseluruhan responden berjumlah 102 orang dan kesemuanya merupakan mahasiswi aktif di UI, dengan rentang usia 17-26 tahun. Sebagian besar $(74 \%)$ responden telah berkuliah selama lebih dari 1 tahun, sehingga sudah memiliki pengalaman yang cukup banyak dengan lingkungan kampus dan kemungkinan telah beradaptasi dengan kehidupan kampus. Namun, tidak dapat dikatakan bahwa mahasiswi tahun pertama lebih berpotensi merasakan takut daripada para seniornya.

Mahasiswi yang berpartisipasi berasal dari 5 Fakultas yang ada di UI. Mayoritas responden berasal dari Fakultas Teknik (sebanyak 93 orang, atau $91 \%)$, dan lainnya (9\%) berasal dari Fakultas Ekonomi dan Bisnis, Fakultas Kedokteran, Fakultas Ilmu Keperawatan dan Fakultas Ilmu Administrasi. Sebanyak 58.8\% responden berdomisili di sekitar kampus, baik di asrama maupun di rumah kos yang terletak dekat dengan kampus. 41,2\% responden tinggal bersama orang tua atau sanak saudaranya. Mahasiswi yang tinggal di seputaran kampus memiliki frekuensi kontak yang lebih banyak dengan area ambang kampus. Selain untuk bertransisi keluar dan ke dalam kampus, di sepanjang area ini terdapat banyak fungsi komersial yang menyediakan kebutuhan makanan dan keperluan mahasiswa lainnya.

Tabel 2. Karakteristik Sampel

\begin{tabular}{|ll|l|}
\hline \multicolumn{3}{|c|}{ Sample Characteristics $(\mathbf{N}=102)$} \\
\hline Karakteristik & $\begin{array}{l}\text { Jumlah } \\
\text { Sampel } \\
\text { \%(n) }\end{array}$ \\
\hline Usia & 17-26 tahun & \\
\hline Angkatan & Freshman (th-1) & $26.5 \%(26)$ \\
& Sophomore (th-2) & $6.9 \%(7)$ \\
& Junior (th-3) & $29.4 \%(30)$ \\
& Senior (th-4,5) & $37.3 \%(38)$ \\
& Pascasarjana & $1 \%(1)$ \\
\hline Status & & \\
Domisili & On-Campus (asrama) & $3.9 \%(4)$ \\
& Kos di dekat kampus & $54.9 \%(56)$ \\
& Tinggal dengan keluarga & $40.2 \%(41)$ \\
& (off-campus) & \\
\hline
\end{tabular}

\begin{tabular}{|cll|l|}
\hline Fakultas & Fakultas Teknik: & $91 \%(93)$ \\
& - & Arsitektur & $61 \%(63)$ \\
& - & Sipil & $2.9 \%(3)$ \\
& - & Teknik Industri & $5.8 \%(6)$ \\
& & Metalurgi dan \\
& Material & $1 \%(1)$ \\
& & \\
& Faculty Ekonomi dan & $2 \%(2)$ \\
& Bisnis & $1 \%(1)$ \\
& Fakultas Kedokteran & \\
Faculty Ilmu Keperawatan & $2 \%(2)$ \\
& Faculty Ilmu Administrasi & $2 \%(2)$ \\
\hline
\end{tabular}

\subsection{Analisis Viktimisasi Masa Lalu}

Pada bagian kedua dari kuesioner, peneliti mendata pengalaman masa lalu responden yang terkait tindakan kriminalitas atau viktimisasi, yang menurut Sideris (2014) dapat memiliki pengaruh signifikan terhadap persepsi rasa takut seseorang di masa kini. Pengalaman masa lalu ini tidak harus terjadi di lingkungan kampus.

Tabel 3. Pengalaman Viktimisasi di Masa Lampau

\begin{tabular}{|ll|c|}
\hline \multicolumn{2}{|c|}{ Tabel 3. Pengalaman Viktimisasi (n=102) } \\
\hline Pengalaman & Pernah & \% (n) \\
Viktimisasi & Tidak Pernah & $75.5 \%(77)$ \\
\hline Tipe & Catcalling & $24.5 \%(25)$ \\
Kejahatan & Pencopetan & $60.9 \%(56)$ \\
Yang Dialami & Kekerasan Verbal & $35.9 \%(33)$ \\
(multiple & Kekerasan Fisik & $19.6 \%(18)$ \\
selection) & Penguntitan & $17.4 \%(16)$ \\
& Perampokan & $1.1 \%(1)$ \\
& Pembunuhan (saksi) & $1.8 \%(9)$ \\
& Pemerkosaan & - \\
\hline Waktu & Siang Hari & $58.4 \%(52)$ \\
Kejadian & Sore Hari & $16.9 \%(15)$ \\
& Malam Hari & $23.6 \%(21)$ \\
& & \\
\hline
\end{tabular}

Berdasarkan data yang didapatkan pada tabel 3, mengindikasikan bahwa $75.5 \%$ responden pernah menjadi korban ataupun menjadi saksi tindak kejahatan pada masa lalu. Lebih dari separuh responden mengalami gangguan pelecehan (street harassment atau catcalling) saat berada di ruang publik. Meskipun demikian, pelecehan seksual secara verbal masih menjadi perdebatan, apakah dapat dikategorikan sebagai tindakan kriminal dan pelakunya dapat dikriminalisasi ("Could catcalling and wolf-whistling become hate crimes?," n.d.). Untuk keperluan artikel ini, penulis menyertakan catcalling kedalam kategori pelecehan seksual secara verbal, karena dampak yang ditimbulkan oleh tipe pelecehan ini dapat memicu rasa takut dan 
menyebabkan korban melakukan modifikasi perilaku.

Tindak kejahatan lain yang pernah dialami oleh korban kebanyakan berupa tindak kejahatan ringan, seperti pencopetan, penguntitan dan pencurian. Tindak kejahatan berat hanya pernah dialami oleh $9.8 \%$ dari responden. Jenis kejahatan berat yang dialami adalah perampokan terencana, dan seorang responden pernah menjadi saksi aksi pembunuhan. Tindak kejahatan yang dialami responden kebanyakan berlangsung pada pagi hingga siang hari $(58,4 \%)$, hanya $16,9 \%$ yang mengalami kejahatan di sore hari, dan $23,6 \%$ pada malam hari.

Hasil analisis dari bagian kedua ini menunjukkan fakta yang menarik, bahwa tindak kejahatan yang dialami responden sebagian besar berlangsung di kurun waktu pagi hingga siang hari. Hal ini berbeda dengan persepsi umum bahwa kejahatan lebih sering terjadi pada malam hari. Apabila kita melihat tipe kejahatan yang dialami pada siang hari oleh responden, maka dapat dilihat bahwa sebagian besar mengalami tipe kejahatan ringan (pencopetan, pencurian, pelecehan seksual secara verbal atau catcalling di ruang publik). Terdapat dua kemungkinan penjelasan untuk hal tersebut, pertama, mahasiswi cenderung lebih aktif menggunakan ruang publik pada pagi dan siang hari, sehingga pada saat-saat ini ia lebih berpotensi menjadi korban di ruang publik yang diaksesnya (jalan raya, transportasi publik, dan sebagainya). Kedua, pada siang hari mahasiswi tidak akan berada di domisilinya, sehingga dapat menimbulkan kesempatan bagi pelaku kejahatan (pencurian) untuk beraksi di lingkungan tempatnya bertinggal (rumah, koskosan, atau kontrakan). Meskipun persentase responden yang mengalami catcalling sangat besar, namun tipe kejahatan ini sesungguhnya memiliki sifat tidak tergantung kepada waktu (time-dependent). Pelecehan seksual secara verbal dapat terjadi kapanpun, selama masih terdapat ketidaksetaraan akses pada ruang publik, yaitu ketika laki-laki cenderung menunjukkan kuasa dan kontrolnya atas perempuan.

Dengan menggali informasi mengenai pengalaman viktimisasi di masa lampau, maka tim peneliti memiliki gambaran bahwa hampir seluruh responden pernah mengalami tindak kejahatan, yang menurut Loukaitou-Sideris
(2014) dapat mempengaruhi respon mereka terhadap isyarat lingkungan yang memicu perasaan takut. Namun demikian, pada studi awal ini, kami tidak mengkorelasikan pengalaman masa lalu responden dengan persepsi terhadap isyarat lingkungan di masa kini.

\subsection{Isyarat Lingkungan Pemicu Rasa Takut} Pada bagian ketiga dari kuesioner, terdapat pertanyaan spesifik mengenai isyarat lingkungan yang dapat memicu rasa takut pada konteks kampus UI. Pertanyaan pertama pada bagian ini adalah mengenai titik lokasi yang dianggap paling memicu rasa takut responden (lihat gambar 2). Sebanyak 43,4\% responden memilih "Barel" (kependekan dari Balik Rel), yaitu area yang berseberangan dengan Fakultas Hukum. Lokasi yang juga dianggap 'menakutkan' (41,2\%) adalah area transisi antara gedung program Vokasi dengan wilayah Kukusan Kelurahan. Lokasi lainnya yang dianggap memicu rasa takut, dengan urutan sebagai berikut: Kukusan Teknik, Stasiun Pondok Cina, Stasiun UI, Gerbatama (Gerbang Utama UI), Pool Bis Kuning, dan Pusat Kegiatan Mahasiswa (PUSGIWA) UI.

Bila ditinjau dari aspek fisiknya, area Barel (Gambar 3) dihubungkan oleh jalan setapak sempit, yang dibatasi kedua sisinya oleh pagar kuning dan pagar pembatas yang bersisian dengan rel kereta api. Saat seseorang berada di jalan setapak tersebut, ia akan memiliki visibilitas yang terbatas, sehingga sulit untuk memprediksi situasi di depannya, terutama pada saat petang dan malam hari. Pagar yang membatasi setapak di kedua sisi, dapat menimbulkan perasaan terperangkap (entrapment). Apabila ada kereta api yang lewat, maka suara bising yang ditimbulkannya membuat perasaan terperangkap semakin kuat, tingkat kebisingan yang tinggi juga dapat menurunkan kemampuan observasi seseorang terhadap lingkungannya. Tingkat pencahayaan pada setapak relatif kurang, penerangan yang ada tidak dapat menerangi setapak secara merata, sehingga turut mengurangi aspek visibilitas. Meskipun harus melalui setapak sempit dan menyeberang rel kereta api, sehariharinya akses menuju Barel ramai dilalui oleh mahasiswa, terutama oleh mereka yang berdomisili di area tersebut. 
Menurut teori Prospect and Refuge yang dikemukakan oleh Appleton (1984), ruang transisi menuju Barel memenuhi kriteria prospect yang rendah karena kurangnya visibilitas pada jalan setapak. Selain itu, setapak Barel memiliki nilai refuge yang tinggi karena setapak memiliki batas fisik yang memicu perasaan terperangkap (entrapment) sehingga menyulitkan usaha untuk menyelamatkan diri (possibility of escape) apabila terjadi bahaya.
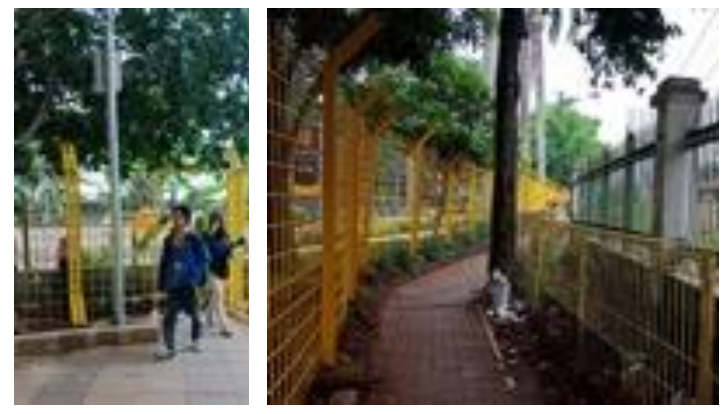

Gambar 3. Kondisi Lingkungan di Area Barel
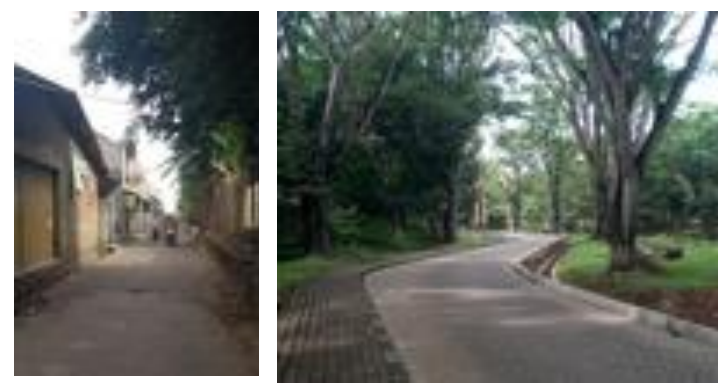

Gambar 4. Kondisi Lingkungan di Kelurahan Kukusan - Gedung Vokasi
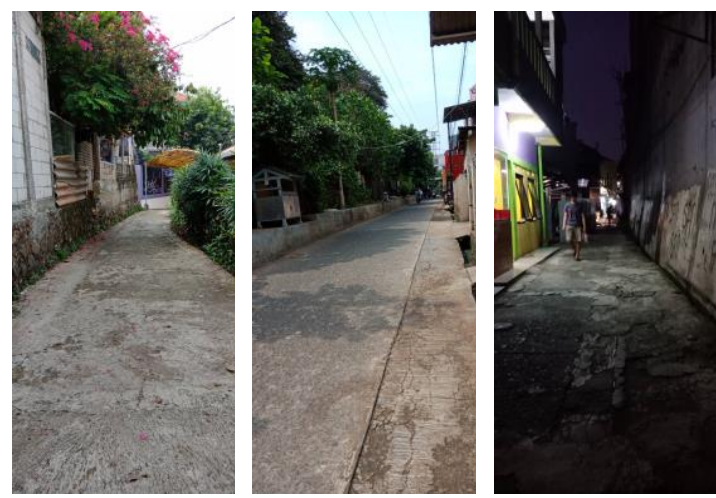

Gambar 5.Kukusan Teknik area
Pada bagian pertanyaan selanjutnya, responden diminta untuk memilih karakteristik lingkungan (berdasarkan tabel 1) yang memicu rasa takut pada titik lokasi terpilih, respon dapat berupa multi jawaban. Hasil dari pertanyaan ini (lihat tabel 4 dan gambar 6) menunjukkan bahwa tingkat pencahayaan yang kurang baik dianggap sebagai isyarat yang paling memicu rasa takut (72,5\% kasus). Selain pencahayaan, terdapat tiga isyarat lain yang memiliki bobot relatif mirip, yaitu lokasi yang tidak terawat (unmaintained), Setapak yang panjang dan sempit, serta tumbuhan yang terlampau lebat (dense foliage). Berdasarkan hasil ini, dapat dianalisis bahwa bagi mahasiswi, kemampuan untuk mengobservasi ruang sangatlah penting, sehingga mereka dapat menilai potensi bahaya yang mungkin terjadi. Ketiga isyarat yang dipilih berikutnya juga menunjukkan bahwa penilaian terhadap konfigurasi dan kualitas ruang, serta potensi ruang yang dapat memperkecil kemungkinan untuk menyelamatkan diri menjadi aspek yang sangat penting bagi mahasiswi dalam menilai isyarat lingkungan.

Sementara itu, isyarat lingkungan yang tidak bersifat membatasi kemampuan observasi dan kemampuan menyelamatkan diri, seperti lingkungan yang ramai, jejak vandalisme, dan ruangan yang tertutup dianggap dapat memicu potensi rasa takut oleh sepertiga dari total responden. Sedangkan, ruangan yang luas dan terbuka dianggap tidak menimbulkan rasa takut oleh sebagian besar responden.

Tabel 4. Respon Terhadap Isyarat Lingkungan yang Memicu Rasa Takut pada Lokasi Observasi

\begin{tabular}{|l|c|c|c|}
\hline \multicolumn{1}{|c|}{ Isyarat Lingkungan } & Jmlh & $\begin{array}{c}\text { \% } \\
\text { respons }\end{array}$ & $\begin{array}{c}\% \\
\text { kasus }\end{array}$ \\
\hline Vandalisme & 18 & $7.4 \%$ & $17.65 \%$ \\
\hline Situasi Padat-Ramai & 23 & $9.4 \%$ & $22.5 \%$ \\
\hline Pencahayaan buruk & 74 & $30.3 \%$ & $72.5 \%$ \\
\hline Tanaman lebat & 35 & $14.3 \%$ & $34.3 \%$ \\
\hline Tidak terawat & 36 & $14.8 \%$ & $35.3 \%$ \\
\hline Lorong sempit & 35 & $14.3 \%$ & $34.3 \%$ \\
\hline Ruang tertutup & 16 & $6.6 \%$ & $15.7 \%$ \\
\hline Ruang terbuka & 7 & $2.9 \%$ & $6.75 \%$ \\
\hline 102 respon valid & 244 & $100 \%$ & $239 \%$ \\
\hline
\end{tabular}




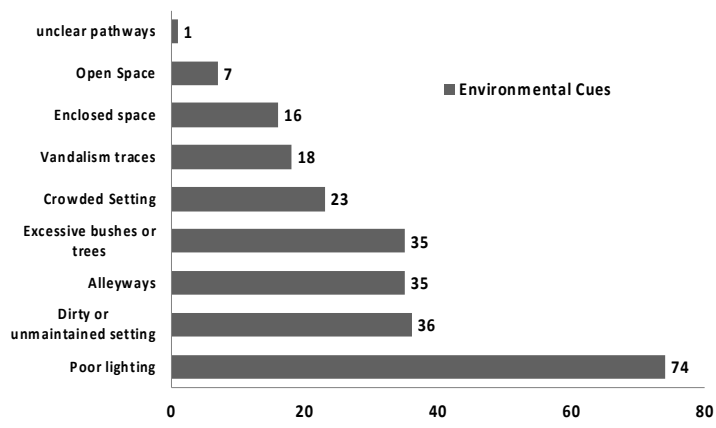

Gambar 6. Pemicu Rasa Takut pada Lokasi Observasi

Bila kita mengamati kondisi fisik lingkungan pada area yang dianggap 'menakutkan' oleh responden (lihat foto 3,4,5), maka hasil yang didapatkan dari bagian ini cukup konsisten dengan isyarat lingkungan yang terdapat pada area Barel, Kukusan Kelurahan-Vokasi dan Kukusan Teknik. Terdapat kesamaan pada ketiga lokasi teresebut, yaitu pada malam hari pencahayaannya relatif minim, setapak yang menghubungkan relatif sempit, panjang dan berliku. Di sepanjang kiri dan kanan setapak terdapat boundary yang kuat, baik berupa pagar pembatas maupun tumbuhan yang lebat.

Bagian selanjutnya dari kuesioner berupaya menggali informasi mengenai setting atau situasi lingkungan yang dapat memicu perasaan takut. Responden diminta untuk menilai tingkat rasa takut mereka dengan menggunakan skala Likert 5 poin. Contoh dari pertanyaan yang diberikan misalnya: "Berjalan di setapak yang pencahayaannya minim membuat saya merasa takut". Hasil analisis pada bagian pertanyaan ini (lihat gambar 7) menunjukkan bahwa isyarat lingkungan yang dipilih responden cukup konsisten dengan hasil pada bagian sebelumnya.

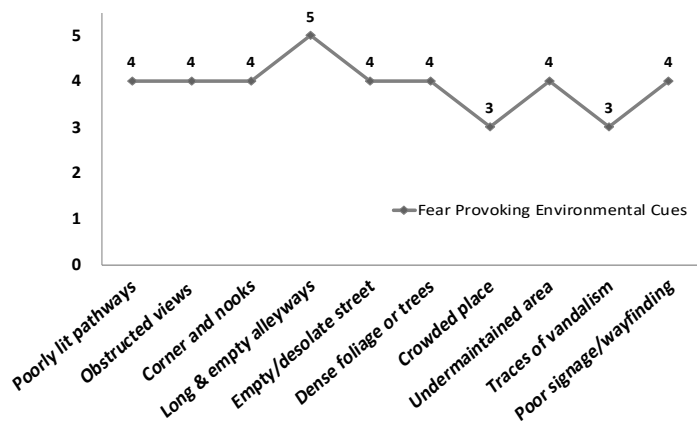

Gambar 7. Tingkat Rasa Takut Berdasarkan Setting
Gambar 7 menunjukkan median dari setiap pertanyaan yang diberikan, yang menjelaskan kecenderungan rasa takut mahasiswi terhadap setting lingkungan tertentu. Setting lingkungan yang diangap paling menimbulkan rasa takut adalah setapak atau gang yang sepi dan sempit (median= 5). Hasil ini sejalan dengan karakteristik lokasi yang dipilih responden sebagai yang paling menakutkan, yaitu pada area Barel (gambar 3). Adapun, setapak yang penerangannya kurang baik dinilai dengan skala median $=4$. Meskipun tingkat rasa takut pada isyarat penerangan cukup tinggi, hasil ini tidak konsisten terhadap hasil pada bagian sebelumnya, dimana pencahayaan yang buruk dipilih sebagai isyarat lingkungan yang paling menakutkan.

Setting lingkungan lain yang dinilai dengan skala sedang (median $=3$ ) atau dinilai biasa saja oleh responden adalah situasi lingkungan yang padat ramai serta jejak vandalisme. Pada situasi yang ramai, perempuan lebih dapat mencari pertolongan apabila dalam keadaan bahaya. Sedangkan, jejak vandalisme dianggap tidak mengganggu potensi observasi dan potensi melarikan diri dalam situasi bahaya. Oleh karenanya, kedua isyarat ini dianggap tidak terlalu memicu perasaan takut.

Selain inkonsistensi pada isyarat pencahayaan, tingkat rasa takut terhadap isyarat lainnya pada bagian ini konsisten terhadap hasil pada bagian sebelumnya.

\subsection{Setting Lingkungan Yang Dianggap Aman}

Pada penghujung kuesioner, responden diminta untuk memilih setting lingkungan yang dianggap dapat memberikan rasa aman (lihat tabel 5 dan gambar 8). Hasilnya, keberadaan polisi atau pihak berwajib lainnya dapat memunculkan perasaan aman, karena dianggap mampu mengendalikan situasi. Hasil ini sejalan dengan pernyataan Fisher \& May (2009), bahwa perempuan tidak bergantung kepada kekuatan fisiknya saat menghadapi situasi bahaya, sehingga keberadaan petugas resmi (officials) dianggap lebih dapat memberikan jaminan keselamatan. 
Tabel 5. Respon Terhadap Setting Yang Dianggap Memunculkan Perasaan Aman

\begin{tabular}{|c|c|c|c|}
\hline Setting Lingkungan & Jmlh & $\begin{array}{c}\text { \% } \\
\text { respons }\end{array}$ & $\begin{array}{c}\text { \% } \\
\text { kasus }\end{array}$ \\
\hline $\begin{array}{c}\text { Kehadiran aparat } \\
\text { keamanan }\end{array}$ & 84 & $27.6 \%$ & $82.4 \%$ \\
\hline Pencahayaan baik & 83 & $27.3 \%$ & $81.4 \%$ \\
\hline Akses visual yang baik & 62 & $20.4 \%$ & $60.8 \%$ \\
\hline Wayfinding baik & 36 & $11.8 \%$ & $34.3 \%$ \\
\hline Instalasi CCTV & 26 & $8.6 \%$ & $25.5 \%$ \\
\hline Adanya papan iklan & 8 & $2.6 \%$ & $7.8 \%$ \\
\hline $\begin{array}{c}\text { Adanya instalasi } \\
\text { seni/mural }\end{array}$ & 5 & $1.6 \%$ & $4.9 \%$ \\
\hline 102 respon valid & 304 & $100 \%$ & $239 \%$ \\
\hline
\end{tabular}

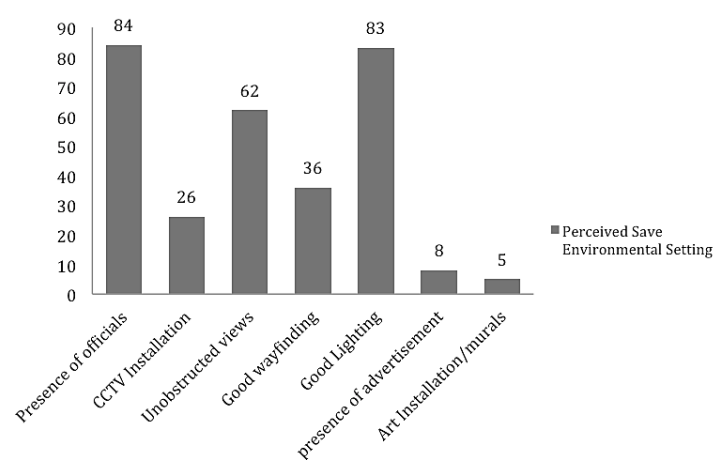

Gambar 8. Persepsi Setting Lingkungan yang Aman

Setting lingkungan yang juga mendapatkan penilaian tinggi adalah tempat dengan pencahayaan yang baik (terang, merata). Aspek pencahayaan memungkinkan seseorang mendapatkan visibilitas yang baik sehingga dapat meningkatkan kemampuan observasi ruang. Berikutnya, kemampuan untuk melihat sekitarnya dengan baik tanpa terhalang (unobstructed views) dinilai sebagai setting lingkungan yang memberikan rasa aman. Hasil ini berhubungan dengan kemampuan seseorang untuk dapat menilai potensi bahaya pada lingkungan, sehingga setting yang memiliki pojok tersembunyi dan sulit terlihat atau tetumbuhan lebat yang berpotensi menjadi tempat persembunyian seseorang dengan niat jahat, merupakan isyarat lingkungan yang sangat tidak diinginkan oleh reseponden.

Aspek yang juga dianggap cukup penting oleh responden adalah alur dan penanda jalan yang jelas. Kemampuan memahami posisi dalam ruang dan sense of direction yang baik dianggap dapat membantu meredakan rasa takut seseorang, terutama apabila berada pada lingkungan yang kurang familiar.
Keberadaan teknologi pengawasan ruang, misalnya CCTV, dianggap cukup membantu oleh $1 / 4$ dari jumlah responden. Hasil ini cukup relevan dengan hasil penelitian Yavuz \& Welch yang menyatakan bahwa keberadaan CCTV dianggap tidak memberikan dampak rasa aman yang signifikan, dibandingkan dengan kehadiran seorang petugas polisi (Yavuz \& Welch, 2010). Mahasiswi lebih memilih kehadiran fisik petugas keamanan karena dianggap dapat lebih cepat menanggapi situasi bahaya.

Adapun, keberadaan iklan, mural maupun karya seni tidak dianggap sebagai hal yang dapat membantu menghilangkan rasa takut. Hal ini mengindikasikan bahwa responden lebih peka pada isyarat yang berasal dari konfigurasi fisik sebuah setting dibandingkan dengan perlakuan pada bidang (surface embellishment). Berdasarkan hasil dari bagian ini, dapat dilihat bahwa mahasiswi lebih memilih setting yang membuatnya dapat menghindari bahaya tanpa harus mengandalkan kekuatan fisik dan sangat bergantung kepada kemampuan observasinya untuk menilai isyarat lingkungan.

\section{KESIMPULAN}

Berdasarkan survei yang dilakukan terhadap ambang kampus UI, beberapa lokasi dianggap responden menimbulkan rasa takut (Gambar 35). Isyarat lingkungan yang memicu persepsi rasa takut hampir seluruhnya disebabkan oleh karakteristik lingkungan tersebut, yang terdiri atas konfigurasi ruang (misalnya: gang, lorong) dan kualitas ruang (misal: gelap,kotor, mengungkung).

Hasil analisis terhadap beberapa titik lokasi yang dianggap memicu rasa takut responden dengan menggunakan indikator yang tertera pada tabel 1, menunjukkan bahwa isyarat lingkungan yang paling memicu rasa takut mahasiswi adalah ketika visibilitas dan kemampuan mengamati kondisi sekitarnya terbatas. Isyarat lingkungan yang berperan dalam visibilitas dan observasi adalah tingkat pencahayaan serta adanya konfigurasi dan elemen ruang yang dapat menghalangi pandangan (ruang dengan terlalu banyak sudut dan pojok, tumbuhan yang terlalu lebat). Setting lingkungan yang membatasi kemampuan seseorang untuk melarikan diri 
juga dianggap memicu rasa takut, misalnya pada lorong yang panjang dan sempit. Namun, jejak vandalisme dan lingkungan yang kurang terawat dianggap tidak memberikan rasa takut yang terlalu signifikan. Karena, lingkungan yang kurang terawat dan adanya vandalisme tidak terlalu memengaruhi kemampuan observasi dan kesempatan untuk menyelamatkan diri.

Isyarat sosial seperti situasi yang padat dan ramai oleh orang asing dianggap responden sebagai situasi yang tidak menimbulkan rasa takut. Hal ini sejalan dengan penelitian oleh Fisher \& May (2009) yang menyatakan bahwa perempuan lebih cenderung menilai resiko bahaya berdasarkan keadaan atau ketiadaan isyarat lingkungan tertentu. Berbeda dengan laki-laki yang lebih bisa mengandalkan kekuatan fisiknya dalam situasi berbahaya, perempuan lebih memilih untuk mengamati isyarat lingkungan untuk menilai resiko bahaya daripada menilai isyarat sosial.

Temuan lain yang cukup menarik pada penelitian ini adalah bahwa meskipun isyarat lingkungan dianggap lebih dapat memicu rasa takut, namun pada saat menjawab pertanyaan mengenai perlakuan terhadap lingkungan yang dianggap bisa memberi rasa aman (fear relieving), responden sebagian besar memilih isyarat sosial, yaitu kehadiran polisi atau aparat keamanan. Namun, penerapan teknologi CCTV dianggap tidak memberikan rasa aman yang signifikan. Hasil ini sejalan dengan penelitian yang dilakukan oleh Yavuz \& Welch (2010), bahwa kehadiran polisi di suatu tempat dianggap lebih dapat memberikan jaminan rasa aman dibandingkan dengan aplikasi teknologi (CCTV). Bagi perempuan, rasa aman lebih bisa didapatkan dari isyarat langsung, oleh karenanya kehadiran fisik menjadi lebih dihargai dibandingkan dengan isyarat yang diperantarai dan tidak dapat segera merespon kondisi bahaya, seperti halnya teknologi CCTV.

Penelitian ini dapat dilanjutkan dengan menguji secara kuantitatif tiap-tiap isyarat lingkungan pemicu rasa takut yang teridentifikasi, apakah terdapat konfigurasi atau karakteristik tertentu dari isyarat yang memicu perasaan takut tersebut.

Melalui studi mengenai isyarat lingkungan pemicu rasa takut ini, penulis berharap persepsi bahaya dan rasa takut terhadap kejahatan dapat dipahami lebih luas oleh berbagai pihak, seperti perancang, penentu kebijakan dan pengelola fasilitas umum. Sehingga, beragam tindakan pencegahan dapat dilakukan untuk memastikan rasa aman perempuan, bukan hanya terbatas pada lingkungan kampus, namun juga pada berbagai fasilitas publik di kota.

\section{REFERENSI}

Appleton, J. (1984). Prospects and Refuges ReVisited. Landscape Journal, 3(2).

Boettger, T. (2014). Threshold Spaces: Transitions in Architecture. Basel: Birkhauser.

Could catcalling and wolf-whistling become hate crimes? (n.d.). Retrieved November 11, 2018, from BBC News Online website: https://www.bbc.com/news/ukpolitics-43303874

Day, K. (1994). Conceptualizing women's fear of sexual. Environment and Behavior, Vol. 26.

Dwika, R. (2015). Waspada! Kala Kriminalitas Melanda Civitas.

Ferraro, K. F. (1996). Women's Fear of Victimization: Shadow of Sexual Assault? Social Forces, 75(2), 667-690. Retrieved from https://www.jstor.org/stable/2580418

Fisher, B. S., \& May, D. (2009). College students' crime-related fears on campus: Are fear-provoking cues gendered? Journal of Contemporary Criminal Justice, 25(3), 300-321. https://doi.org/10.1177/10439862093350 13

Fisher, B. S., \& Sloan, J. J. (2003). Unraveling the fear of victimization among college women: Is the "shadow of sexual assault hypothesis" supported? Justice Quarterly, 20(3), 633-659. https://doi.org/10.1080/07418820300095 641

Loukaitou-sideris, A. (2012). Safe on the Move: The Importance of the Built Environment. In V. Ceccato (Ed.), The Urban Fabric of Crime and Fear. Springer.

Loukaitou-Sideris, A. (2014). Fear and safety in transit environments from the women's perspective. Security Journal, 27(2), 242256. https://doi.org/10.1057/sj.2014.9 
Loukaitou-Sideris, A., Bornstein, A., Fink, C., Samuels, L., \& Gerami, S. (2009). How to Ease Women's Fear of Transportation Environments: Case Studies and Best Practices. San José, CA.

Loukaitou-sideris, A., \& Fink, C. (2008). Addressing Women's Fear of Victimization in A Survey of U . S . Transit Agencies. Urban Affairs Review, $1-34$.

Mellgren, C., \& Ivert, A. K. (2018). Is Women's Fear of Crime Fear of Sexual Assault? A Test of the Shadow of Sexual Assault Hypothesis in a Sample of Swedish University Students. Violence Against Women, 1-17. https://doi.org/10.1177/10778012187932 26

Nurdiansyah, R. (2015). Kampus UI Rentan Kejahatan dan Narkoba. Republika Online. Retrieved from https://www.republika.co.id/berita/nasion al/hukum/15/04/10/nmjup0-kampus-uirentan-kejahatan-dan-narkoba

PLK UI. (2013). Angka Kriminalitas di Kampus UI.

Putra, B. (2018). 2 Pencuri di Lingkungan Kampus UI Depok Diringkus Polisi, Ternyata Sudah Beraksi 7 Kali. Retrieved December 11, 2018, from Tribun News website:

http://jakarta.tribunnews.com/2018/11/07 /2-pencuri-di-lingkungan-kampus-uidepok-diringkus-polisi-ternyata-sudahberaksi-7-kali\#gref

Rader, N. (2017). Fear of Crime. https://doi.org/10.1093/acrefore/9780190 264079.013.10

Stanko, E. A. (1995). Women, Crime, and Fear. The Annals of the American Academy of Political and Social Science, 539(May 1995), 46-58. Retrieved from https://www.jstor.org/stable/1048395\%0

A

Tentang Universitas Indonesia. (n.d.). Retrieved January 2, 2019, from http://www.ui.ac.id/about-us-2.html

Valentine, G. (1990). Women's Fear and the Design of Public Space. Built Environment, 16(4), 288-303.

Yavuz, N., \& Welch, E. W. (2010). Addressing fear of crime in public space: Gender differences in reaction to safety measures in train transit. Urban Studies, 47(12), 2491-2515.

https://doi.org/10.1177/00420980093590 33 